\title{
ANALISIS PERSEPSI DAN KEPUASAN KONSUMEN RESTORAN PECEL LELE LELA
}

\author{
${ }^{1 *}$ Doni Sahat Tua Manalu \\ Dosen Politeknik Agroindustri \\ Jl. Margamulya No. 27, Ciasem Girang, Kec. Ciasem, Kabupaten Subang, Jawa \\ Barat 41256 \\ Email korespondensi : manaludoni@gmail.com
}

Naskah diterima: 6 Februari 2020 Direvisi: 25 Juli 2020 Disetujui terbit: 10 Agustus 2020

\begin{abstract}
ABSTRAK
Pecel Lele Lela telah meraih penghargaan sebagai usaha mengenalkan lele paling inovatif dari Kementerian Perikanan dan Kelautan RI. Tujuan dilakukannya penelitian ini yaitu dapat mengetahui bagaimana persepsi dan kepuasan pelanggan, sebagai salah satu metode yang dapat digunakan adalah Importance Performance Analysis (IPA) dan metode Customer Satisfaction Index (CSI). Berdasarkan uji validitas data, didapatkan 5 (lima) atribut pada kuesioner tidak valid, sedangkan untuk uji reliabilitas menyatakan bahwa seluruh Aspek yang diteliti dapat diandalkan. Hasil analisis persepsi konsumen pecel lele lela menunjukkan bahwa dimensi yang menurut konsumen penting adalah dimensi responsiveness dan Emphaty. Berdasarkan hasil analisis Indeks Performance Analysis, atribut yang perlu ditingkatkan dan diprioritaskan untuk dibenahi adalah Pelayan stand-by dalam menanggapi konsumen, pengaturan calon pelanggan ketika waiting-list, dan pelayan segera membersihkan meja makan ketika konsumen selesai makan. Berdasarkan hasil penghitungan Customer Satisfaction Index, tingkat kepuasan pelanggan adalah sebesar $79,738 \%$. Hasil ini tentu menjadi dasar evaluasi untuk meningkatkan dan memperbaiki atribut yang menjadi prioritas utama restoran.
\end{abstract}

Kata Kunci : Analisis Persepsi, Kepuasan Konsumen, Pecel lele

\begin{abstract}
Pecel Lele lela has won awards as an attempt to introduce the most innovative catfish from the Indonesian Ministry of Fisheries and Maritime Affairs. The purpose of this study is to discuss customer perceptions and satisfaction, as one of the methods that can be used is the Importance Performance Analysis (IPA) and the Customer Satisfaction Index (CSI) method. Based on the validity test data, obtained 5 (five) attributes on the questionnaire are invalid, while for the reliability test stated all aspects obtained can be obtained. The results of the analysis of consumer perception of catfish pecel indicate dimensions that according to consumers are important are responsive and empathic dimensions. Based on the results of the analysis, Performance Analysis, the attributes that need to be improved and prioritized to be addressed are Waiters, in accordance with customer approval, the preparation of prospective customers waiting list compilation, and the waiter immediately prepares the dining table to compile the consumer after eating. Based on the results of the calculation of the Customer Satisfaction Index, the level of customer satisfaction is $79.738 \%$. These results certainly become the basis of evaluation to improve and improve the attributes that are the top priority of the restaurant.
\end{abstract}

Key words : Consumer Satisfaction, Perception Analysis, Pecel lele 


\section{PENDAHULUAN}

Jumlah populasi negara Indonesia yang mencapai 237.641.326 orang (BPS, 2010), menunjukan bahwa dalam kegiatan berbisnis di Indonesia akan memiliki semakin banyak pesaing. Peningkatan jumlah penduduk Indonesia dari tahun ke tahun sejalan dengan peningkatan konsumsi atau pengeluaran untuk pembelian makanan dari tahun ke tahun. Rata-rata pengeluaran per kapita di kota dalam sebulan di Indonesia untuk keperluan konsumsi makanan pada tahun 2015 dapat mencapai Rp 457.312 (BPS, 2017). Pengeluaran penduduk Indonesia untuk konsumsi makanan juga selalu mengalami peningkatan dalam 3 tahun terakhir. Pada tahun 2016, rata-rata pengeluaran per kapita di kota dalam sebulan di Indonesia untuk keperluan konsumsi makanan mencapai Rp 520.631, kemudian pada tahun 2017 sebesar Rp 590.082. Data tersebut menunjukan bahwa industri makanan dan kuliner di Indonesia cukup potensial untuk digali dan dikembangkan, mengingat tingginya konsumsi makanan per kapita dan jumlah populasi manusia di Indonesia.

Berdasarkan data Badan pusat statistik (BPS, 2015), rata-rata pendapatan kotor restoran di Indonesia dalam setahun pada tahun 2015 mencapai Rp 4.663.825.050. Selain itu, berdasarkan data BPS (BPS, 2015) mengenai statistik restoran Indonesia tahun ke tahun, pertumbuhan restoran dari periode ke periode sangat tinggi dengan persentase sebesar 5,01\% (tahun 1981-1990), 10,55\% (tahun 1991-1998), $42,85 \%$ (tahun 1999-2009), dan 38,57\% (setelah tahun 2009); meskipun pada periode setelah tahun 2009 pertumbuhan restoran tidak setinggi periode sebelumnya.

Pada era globalisasi hingga tahun 2017, kegiatan berbisnis menjadi hal yang biasa dilakukan manusia di seluruh belahan dunia. Bisnis dalam arti luas adalah suatu istilah umum yang menggambarkan suatu aktivitas dan institusi yang memproduksi barang dan jasa dalam kehidupan sehari-hari (Amirullah dan Hardjanto 2005). Salah satu bisnis yang sering dijalankan adalah bisnis kuliner atau restoran.

Rumah makan merupakan jenis bisnis yang menjanjikan. Bisnis usaha seperti ini bila dikembangkan dengan teknik dan pendekatan pasar yang benar akan mendatangkan keuntungan yang besar bagi pemiliknya, oleh sebab itu tidak sedikit para pengusaha yang melirik jenis bisnis ini. Salah satu restoran dengan konsep agribisnis adalah Pecel Lele Lela yang didirikan pada tahun 2006 dan telah mengantongi penghargaan sebagai usaha mengenalkan lele paling inovatif dari Kementrian Perikanan dan Kelautan RI, sekaligus mendorong peningkatan 
konsumsi ikan. Lele yang digunakan sebagai bahan baku adalah lele segar yang didatangkan langsung dari peternakan lele yang sudah menjadi mitra sehingga standarisasi bahan baku sangat terjamin.

Selain standarisasi bahan baku sangat terjamin ada variabel lain yang perlu diperhatikan untuk dapat menjamin terciptanya kepuasan pelanggan. Beberapa diantaranya adalah cita rasa makanan dan kualitas pelayanan di restoran, kondisi ini menjadi kendala karena masih ditemukannya kritik dan saran konsumen terhadap perlunya peningkatan cita rasa makanan dan kualitas pelayanan. Hal tersebut menjadi latar belakang penelitian ini dilakukan, sedangkan tujuan dilakukannya penelitian ini yaitu dapat mengetahui bagaimana persepsi dan kepuasan pelanggan Pecel Lele Lela. Manfaat lainnya adalah mengetahui dimensi apa yang diprioritaskan untuk ditingkatkan dan mengetahui dimensi mana yang sudah baik. Salah satu metode yang dapat digunakan adalah Importance Performance Analysis (IPA). Selain metode IPA, metode lain yang dapat mendukung perbaikan atribut adalah metode Customer Satisfaction Index (CSI) untuk mengetahui tingkat kepuasan konsumen.

\section{METODE PENELITIAN}

\section{Lokasi dan Waktu Penelitian}

Lokasi penelitian dipilih secara sengaja (purposive) dengan pertimbangan bahwa pecel lelel lela banyak di kunjungi oleh konsumen yaitu cabang Pecel lele lela di Tebet, Jakarta Selatan. Pengambilan data dilakukan pada tanggal 1 April 2018 hingga 27 Juli 2018.

\section{Jenis Penelitian}

Desain penelitian ini menggunakan desain penelitian kausal. Penelitian kausal adalah salah satu tipe penelitian konklusif dimana mempunyai tujuan utama untuk mengetahui dan memperoleh bukti mengenai hubungan sebab-akibat (Malhotra 2004). Hubungan sebabakibat pada penelitian ini untuk mengungkapkan pengaruh kualitas layanan terhadap kepuasan pelanggan Resto Pecel Lele Lela. Pendekatan penelitian yang digunakan dalam penelitian ini adalah metode penelitian kuantitatif dan kualitatif. Sugiyono (2004) menyatakan bahwa metode penelitian kuantitatif menekankan analisisnya pada data-data numeric (angka) yang diolah dengan metode statistika. Pendekatan kuantitatif biasanya dilakukan pada penelitian inferensial dan menyandarkan kesimpulan pada pengujian hipotesis. 


\section{Teknik Pemilihan Responden}

Adapun responden dalam penelitian ini dipilih secara sengaja (purposive) dengan kriteria utama adalah konsumen yang pernah membeli dan makan minimal satu bulan terakhir di pecel lele lela di Tebet, Jakarta Selatan sejumlah 50 orang responden. Adapun dasar pemilihan jumlah responden adalah sesuai dengan syarat jumlah responden untuk uji coba disyaratkan minimal 30 responden, dimana dengan jumlah minimal ini distribusi skor/nilai akan lebih mendekati kurva normal (Umar, 2002). Responden dengan jumlah 50 orang diharapkan dapat menggambarkan dari populasi yang ada.

\section{Uji Validitas dan Reliabilitas}

Validitas adalah tingkat keandalan dan kesahihan alat ukur yang digunakan. Intrumen dikatakan valid berarti menunjukkan alat ukur yang dipergunakan untuk mendapatkan data itu valid atau dapat digunakan untuk mengukur apa yang seharusnya di ukur (Sugiyono, 2004). Dengan demikian, instrumen yang valid merupakan instrumen yang benar-benar tepat untuk mengukur apa yang hendak di ukur atau dapat dikatakan Validitas (Validity) yaitu sejauh mana suatu alat ukur tepat dalam mengukur suatu data, dengan kata lain apakah alat ukur yang dipakai memang mengukur sesuatu yang ingin diukur. Suatu variabel atau pertanyaan dikatakan valid apabila skor variable atau pertanyaan tersebut berkorelasi secara signifikan dengan skor total Wahyuningsih (2007).

Reliabilitas adalah ukuran yang menujukkan bahwa alat ukur yang digunakan dalam penelitian keperilakukan mempunyai keandalan sebagai alat ukur, diantaranya di ukur melalui konsistensi hasil pengukuran dari waktu ke waktu jika fenomena yang diukur tidak berubah (Zulganef, 2006). Sementara validitas adalah suatu ukuran yang menunjukkan bahwa variabel yang diukur memang benarbenar variabel yang hendak diteliti oleh peneliti (Zulganef, 2006). Atau dapat dikatakan Reliabilitas adalah suatu ukuran yang menunjukkan sejauh mana hasil pengukuran tetap konsisten bila diukur beberapa kali dengan alat ukur yang sama. Penelitian memerlukan data yang betul-betul valid dan reliabel.

Metode Analisa Data : Indeks Performance Analysis (IPA) dan Customer Satisfaction Index (CSI)

Analisis tingkat kepuasan konsumen Pecel Lele Lela menggunakan Customer Satisfaction Indeks (CSI) yang diolah dengan software microsoft excel, dan untuk mengetahui rekomendasi perbaikan atribut maka digunakan Importance Performance Analysis menggunakan software SPSS. Customer 
Satisfaction Indeks (CSI) merupakan analisis kuantitatif berupa persentase pengguna yang senang dalam suatu survei kepuasan pengguna dan diperlukan untuk mengetahui tingkat kepuasan penguna secara menyeluruh dengan memperhatikan tingkat kepentingan dari atribut-atribut produk atau jasa. Perhitungan keseluruhan CSI menurut Maiyanti et al. (2010) adalah sebagai berikut:

$$
\mathrm{CSI}=\frac{T}{5 Y}
$$

Dimana:

$\mathrm{T}=$ Total Score

$\mathrm{I}=$ Kepentingan

$\mathrm{P}=$ Kinerja,

$\mathrm{Y}=$ Total Kepentingan.

Metode Importance Performance

Analysis (IPA) adalah mencari hubungan antara tingkat kepentingan dan tingkat kepuasan (performance). Perbandingan performance dan importance dirangkum dalam suatu diagram cartecius, yang terbagi atas empat kuadran. Penilaian tingkat kinerja yang dapat mempengaruhi kepuasan konsumen $(\mathrm{X})$ dan penilaian tingkat kepentingan ( $\mathrm{Y}$ ). Total penilaian tingkat kinerja dan kepentingan diperoleh dengan cara menjumlahkan skor penilaian yang diberikan konsumen. Hasil perhitungan akan digambarkan dengan diagram cartesius. Masing-masing atribut diposisikan dalam diagram tersebut berdasarkan skor rata-rata, dimana skor rata-rata penilaian kinerja $(X)$ menunjukkan posisi suatu atribut pada sumbu $\mathrm{X}$ sedangkan atribut pada sumbu $y$ ditunjukkan oleh skor rata-rata tingkat kepentingan (Y). Selanjutnya setiap atribut tersebut dijabarkan dengan diagram kartesius seperti yang terlihat pada Gambar 1.

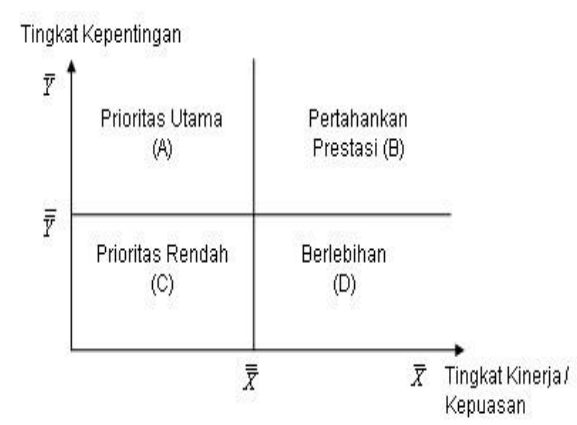

Gambar 1. Diagram cartesius importance performance analysis

Masing masing kuadran (Gambar 1) menunjukkan keadaan yang berbeda :

1. Kuadran 1 (Prioritas Utama)

Wilayah yang memuat item-item dengan tingkat kepentingan yang relatif tinggi tetapi kenyataannya belum sesuai dengan harapan pengguna. Item-item yang masuk kuadran ini harus segera di tingkatkan kinerjanya.

2. Kuadran 2 (Pertahankan Prestasi)

Wilayah yang memuat item-item yang memiliki tingkat kepentingan relatif tinggi dengan tingat kepuasan yang relatif tinggi. Item yang masuk kuadran ini dianggap sebagai faktor penunjang bagi kepuasan pengguna sehingga harus tetap dipertahankan 
karena setiap item ini menjadikan produk/jasa tersebut unggul dimata pengguna.

3. Kuadran 3 (Prioritas Rendah)

Wilayah yang memuat item-item yang memiliki tingkat kepentingan relatif rendah dan kenyataan kinerjanya tidak terlalu istimewa dengan tingat kepuasan yang relatif rendah. Item yang masuk kuadran ini memberikan pengaruh sangat kecil terhadap manfaat yang dirasakan pengguna.

\section{Kuadran 4 (Berlebihan)}

Wilayah yang memuat item-item yang memiliki tingkat kepentingan relatif rendah dan dirasakan oleh pengguna terlalu berlebihan dengan tingkat kepuasan yang relatif tinggi. Biaya yang digunakan untuk menunjang item yang masuk kuadran ini dapat dikurangi agar dapat menghemat biaya pengeluaran (Rangkuti, 2003).

\section{HASIL DAN PEMBAHASAN}

\section{Uji Validitas}

Uji validitas dilakukan dengan turun secara langsung ke pecel lele lela untuk membagikan kuesioner. Responden total dalam penelitian ini adalah 50 responden. Hasil uji validitas aspek reliability pecel lele lela (Tabel 1) menunjukkan bahwa terdapat 1 (satu) pertanyaan yang tidak valid karena $r$ hitung lebih kecil dari $r$ tabel.
Pertanyaan yang tidak valid adalah mengenai jam operasional restoran.

Tabel 1. Uji validitas Kuesioner Aspek Reliability Pecel Lele Lela

\begin{tabular}{lccc}
\hline Pertanyaan & $\begin{array}{c}\mathbf{R} \\
\text { hitung }\end{array}$ & $\begin{array}{c}\text { R } \\
\text { tabel }\end{array}$ & Keterangan \\
\hline Produk & & & \\
yang & & & \\
disajikan & 0,610 & 0,3 & Valid \\
sesuai & & & \\
dengan & & & \\
pesanan & & & \\
Jam operasi & & & \\
restoran & 0,143 & 0,3 & Tidak Valid \\
sesuai & & & \\
harapan & & & \\
Restoran & & & \\
selalu & & & \\
mengangkat & 0,419 & 0,3 & Valid \\
telepon dari & & & \\
pelanggan & & & \\
Produk & & & \\
yang dijual & 0,578 & & \\
selalu fresh & & & \\
Porsi setiap & & & \\
menu sesuai & & & \\
\hline
\end{tabular}

Kemudian hasil uji validitas aspek Tangible pecel lele lela (dapat diihat pada Tabel 2.) menunjukkan bahwa terdapat 2 (dua) pertanyaan yang tidak valid karena $r$ hitung lebih kecil dari $\mathrm{r}$ tabel. Pertanyaan tersebut yang tidak valid adalah mengenai kebersihan dan kelengkapan alat makan dan kejelasan buku menu dalam menjelaskan produk dan harga. 
Tabel 2. Uji validitas Kuesioner Aspek Tangible Pecel Lele Lela

\begin{tabular}{lccc}
\hline Pertanyaan & $\begin{array}{c}\mathbf{R} \\
\text { hitung }\end{array}$ & $\begin{array}{c}\mathbf{R} \\
\text { tabel }\end{array}$ & Keterangan \\
\hline $\begin{array}{l}\text { Kebersihan } \\
\text { alat dan }\end{array}$ & & & \\
perlengkapan & 0,262 & 0,3 & Tidak Valid \\
makan & & & \\
terjaga & & & \\
Tata ruang & 0,636 & 0,3 & Valid \\
restoran baik & & & \\
$\begin{array}{l}\text { Peralatan } \\
\text { makan yang }\end{array}$ & 0,513 & 0,3 & Valid \\
tersedia & & & \\
lengkap & & & \\
Penampilan & & & \\
karyawan & 0,446 & 0,3 & Valid \\
baik & & & \\
Buku menu & & & \\
menjelaskan & & & \\
produk dan & 0,054 & 0,3 & Tidak Valid \\
harga secara & & & \\
jelas & & & \\
\hline
\end{tabular}

Hasil uji validitas aspek Responsiveness pecel lele lela (dapat diihat pada Tabel 3.) menunjukkan bahwa semua pertanyaan valid karena $r$ hitung lebih besar dari $r$ tabel.

Tabel 3. Uji validitas Kuesioner Aspek Responsiveness Pecel Lele Lela

\begin{tabular}{lccl}
\hline Pertanyaan & $\begin{array}{c}\text { R } \\
\text { hitung }\end{array}$ & $\begin{array}{c}\text { R } \\
\text { tabel }\end{array}$ & Keterangan \\
\hline Pelayanan & 0,570 & 0,3 & Valid \\
yang cepat & & & \\
$\begin{array}{l}\text { Pelayan } \\
\text { stand-by }\end{array}$ & & & \\
dalam & 0,528 & 0,3 & Valid \\
menanggap & & & \\
i konsumen & & & \\
$\begin{array}{l}\text { Pengaturan } \\
\text { calon }\end{array}$ & 0,567 & 0,3 & Valid \\
pelanggan & & & \\
\hline
\end{tabular}

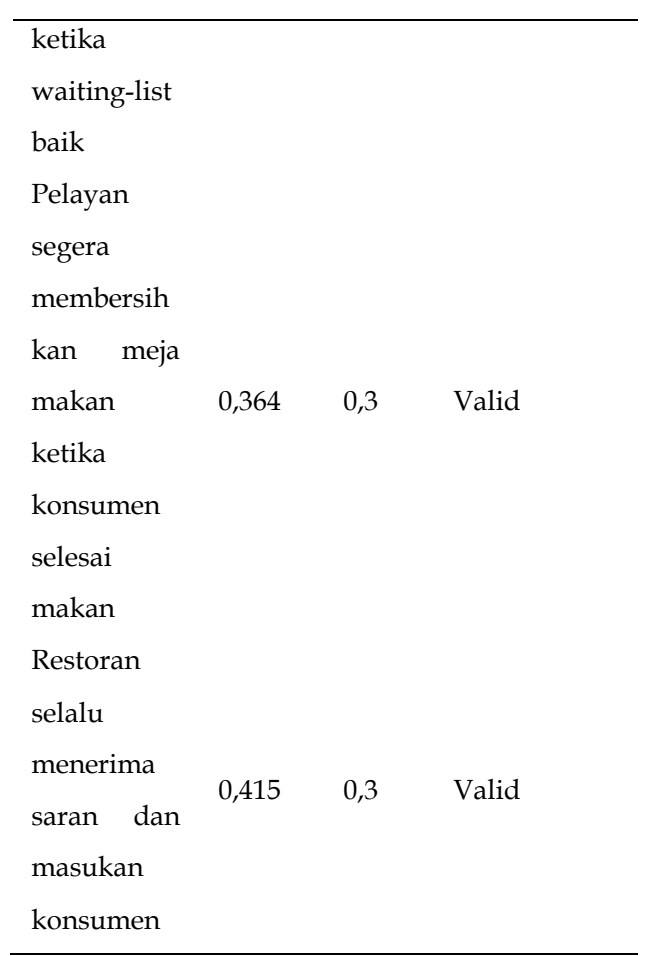

Hasil uji validitas aspek Assurance pecel lele lela (dapat diihat pada Tabel 4.) menunjukkan bahwa terdapat 2 (dua) pertanyaan yang tidak valid. Pertanyaan tersebut yang tidak valid adalah mengenai kesesuaian menu dengan deskripsi pelayan dan kepastian produk selalu ada/ tidak kosong.

Tabel 4. Uji validitas Kuesioner Aspek

\begin{tabular}{|c|c|c|c|}
\hline Pertanyaan & $\begin{array}{l}\text { R } \\
\text { hitun } \\
\text { g }\end{array}$ & $\begin{array}{l}R \\
\text { tabe } \\
1\end{array}$ & $\begin{array}{l}\text { Keteranga } \\
\text { n }\end{array}$ \\
\hline $\begin{array}{l}\text { Pengetahuan } \\
\text { pelayan akan } \\
\text { produk baik }\end{array}$ & 0,558 & 0,3 & Valid \\
\hline $\begin{array}{l}\text { Penjelasan } \\
\text { produk di menu } \\
\text { baik }\end{array}$ & 0,603 & 0,3 & Valid \\
\hline $\begin{array}{l}\text { Restoran selalu } \\
\text { menginformasika } \\
\text { n tanggal libur } \\
\text { kepada konsumen }\end{array}$ & 0,497 & 0,3 & Valid \\
\hline Kesesuaian menu & 0,056 & 0,3 & Tidak \\
\hline
\end{tabular}




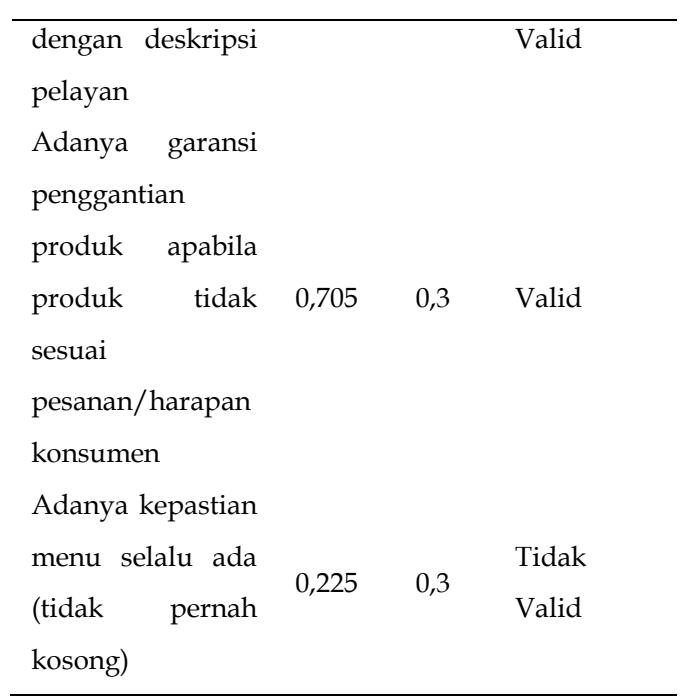

Hasil uji validitas aspek Emphaty pecel lele lela (dapat diihat pada Tabel 5.) menunjukkan bahwa semua pertanyaan lid, karena $\mathrm{r}$ hitung lebih besar dari $\mathrm{r}$ tabel.

Tabel 5. Uji validitas Kuesioner Aspek

\begin{tabular}{|c|c|c|c|}
\hline Pertanyaan & $\begin{array}{l}\mathrm{R} \\
\text { hitung }\end{array}$ & $\mathrm{R}$ tabel & Keterangan \\
\hline $\begin{array}{l}\text { Pelayan } \\
\text { fokus dalam } \\
\text { melayani } \\
\text { pelanggan }\end{array}$ & 0,448 & 0,3 & Valid \\
\hline $\begin{array}{l}\text { Pelayan } \\
\text { berinisiatif }\end{array}$ & & & \\
\hline $\begin{array}{l}\text { menawarkan } \\
\text { menu favorit } \\
\text { kepada } \\
\text { pelanggan }\end{array}$ & 0,304 & 0,3 & Valid \\
\hline $\begin{array}{l}\text { Kesediaan } \\
\text { dan inisiatif } \\
\text { pelayan }\end{array}$ & & & \\
\hline $\begin{array}{l}\text { untuk } \\
\text { membantu }\end{array}$ & 0,398 & 0,3 & Valid \\
\hline ketika & & & \\
\hline $\begin{array}{l}\text { dibutuhkan } \\
\text { pelanggan }\end{array}$ & & & \\
\hline $\begin{array}{l}\text { Pelayan } \\
\text { memiliki }\end{array}$ & 0,377 & 0,3 & Valid \\
\hline
\end{tabular}

\begin{tabular}{l}
\hline sopan \\
santun yang \\
baik
\end{tabular}

\section{Uji Reliabilitas}

Uji reliabilitas pada penelitian ini dilakukan dengan cara menyebar secara langsung kuesioner kepada 50 pelanggan pecel lele lela. Hasil uji reabilitas (Tabel 6.) seluruh aspek penelitian menunjukan angka 0,657. Maka dari itu, dapat disimpulkan bahwa seluruh aspek penelitian pada item pertanyaan dapat diandalkan.

Tabel 6. Uji Reabilitas Seluruh AspekPenelitian Pecel Lele Lela

\begin{tabular}{|c|c|c|}
\hline Variabel & $\begin{array}{l}\text { Nilai Alpha } \\
\text { Cronbach's }\end{array}$ & Keterangan \\
\hline Reliability & \multirow{5}{*}{0,657} & \multirow{5}{*}{$\begin{array}{c}\text { Seluruh } \\
\text { aspek } \\
\text { penelitian } \\
\text { item } \\
\text { pertanyaan } \\
\text { dapat } \\
\text { diandalkan }\end{array}$} \\
\hline Tangible & & \\
\hline Responsiveness & & \\
\hline Assurance & & \\
\hline Emphaty & & \\
\hline
\end{tabular}

\section{Analisis Indeks Performance Analysis}

Letak setiap poin pertanyaan pada kuadran yang berbeda menggambarkan keadaan yang berbeda pula. Pemetaan berdasarkan tingkat kepentingan dan tingkat kinerja ini memungkinkan pihak restoran untuk segera melakukan perbaikan pada atribut yang dianggap penting oleh konsumen dalam jangka waktu yang relatif dekat. Setiap 
kuadran dijelaskan dengan interpretasi sebagai berikut :

1. Kuadran I (Prioritas Utama) :

Pada kuadran ini menggambarkan faktor-faktor yang dianggap penting dan diharapkan oleh konsumen, akan tetapi kinerja restoran belum memberikan kepuasan terhadap apa yang diharapkan konsumen secara optimal, sehingga membuat konsumen merasa kecewa. Dimensi inilah yang perlu diprioritaskan untuk diperbaiki. Atribut yang termasuk pada kuadran I antara lain Pelayan stand-by dalam menanggapi konsumen, pengaturan calon pelanggan ketika waiting-list, dan pelayan segera membersihkan meja makan ketika konsumen selesai makan. Hasil ini dapat menjadi bukti bahwa dimensi responsiveness dari restoran pecel lele lela memang perlu untuk ditingkatkan. Berdasarkan pengalaman peneliti pada saat kunjungan lapang, memang jumlah pegawai yang stand by dalam menanggapi kebutuhan konsumen hanya sekitar 1-2 orang, sehingga wajar apabila hasil variabel pertanyaan yang berada di kuadran 1 semua adalah dimensi responsiveness.
Hal yang sama di kemukakkan oleh Xu dan Goedegeburre (2005) menyatakan bahwa diperlukan adanya pelayan yang siap sedia ketika konsumen menginginkan dan bertanya serta memerlukan bantuan dari pemilik usaha dan hal ini didukung oleh penelitian Swaid, Samar, Wigand, Rolf (2012), Gecti dan Zengin (2013) yang mengungkapkan bahwa kualitas pelayanan akan berpengaruh pada nilai yang dirasakan oleh pelanggan dan pada akhirnya akan mempengaruhi loyalitas pelanggan.

2. Kuadran II (Pertahankan Prestasi) :

Kuadran II merupakan kuadran yang paling diharapkan oleh pelanggan, yang mana kinerja pecel lele lela mengenai atributatribut tersebut telah memuaskan pelanggan. pecel lele lela wajib untuk mempertahankan prestasi kinerja tersebut. Gambar 1. menunjukkan bahwa terdapat 11 (sebelas) atribut yang termasuk dalam kuadran II. Atribut-atribut tersebut antara lain Restoran selalu mengangkat telepon dari pelanggan, Produk yang dijual selalu fresh, Porsi setiap menu sesuai dengan harapan konsumen, Penampilan karyawan 


\begin{abstract}
baik, Adanya garansi penggantian produk apabila produk tidak sesuai pesanan/harapan konsumen, Pelayan fokus dalam melayani pelanggan, Pelayan berinisiatif menawarkan menu favorit kepada pelanggan, Kesediaan dan inisiatif pelayan untuk membantu ketika dibutuhkan pelanggan dan Pelayan memiliki kejujuran apabila ada barang pelanggan yang tertinggal. Berdasarkan hasil kunjungan lapang, didapatkan fakta bahwa pelayan restoran pecel lele lela sangat ramah dan memiliki kesadaran yang tinggi, sehingga hasil penelitian diatas wajar. Hanya kekurangannya adalah di sektor jumlah karyawan yang stand by. Penelitian Ismail dan Shaker (2012) dampak kualitas, produk dan harga akan mempengaruhi kemampuan bersaing perusahaan, oleh karena itu pecel lele lela harus dapat mempertahankan prestasi yang ada saat ini.
\end{abstract}

\section{Kuadran III (Prioritas Rendah) :}

Kuadran III terdapat faktor-faktor yang dianggap mempunyai tingkat kepentingan yang rendah dan tidak terlalu penting atau tidak terlalu diharapkan oleh konsumen sehingga pecel lele lela tidak perlu memprioritaskan atau memberikan perhatian lebih pada faktor-faktor tersebut. Namun, akan lebih baik lagi apabila pecel lele lela tetap memperhatikan atribut tersebut. Gambar 1.menunjukkan bahwa terdapat 7 (tujuh) atribut yang termasuk dalam kuadran III. Atribut-atribut tersebut antara lain Tata ruang restoran baik, Peralatan makan yang tersedia lengkap, Meja kursi nyaman digunakan, Restoran selalu menerima saran dan masukan konsumen, dan Penjelasan produk di menu baik.

4. Kuadran IV (Berlebihan) :

Pada kuadaran ini terdapat faktor-faktor yang dianggap tidak terlalu penting dan tidak terlalu diharapkan oleh pelanggan sehingga pecel lele lela lebih baik mengalokasikan sumber daya yang terkait pada faktor tersebut kepada faktor lain yang lebih memiliki tingkat prioritas lebih tinggi. Gambar 2. menunjukkan bahwa terdapat 4 (empat) atribut yang termasuk dalam kuadran IV. Atribut-atribut tersebut antara lain Produk yang disajikan sesuai dengan pesanan, Pelayanan yang cepat, Pengetahuan pelayan akan produk baik, Restoran selalu menginformasikan tanggal libur kepada konsumen, dan pelayan memiliki sopan santun yang baik. 
Hasil tersebut didukung oleh hasil wawancara peneliti dengan salah satu karyawan bahwa restoran pecel lele lela memang selalu menginfokan jadwal libur jauh hari sebelumnya. Berdasarkan pantauan peneliti, pelayan sangat baik dalam memahami deskripsi menu restoran dan memiliki pengetahuan yang baik dalam hal menjelaskan isi menu.

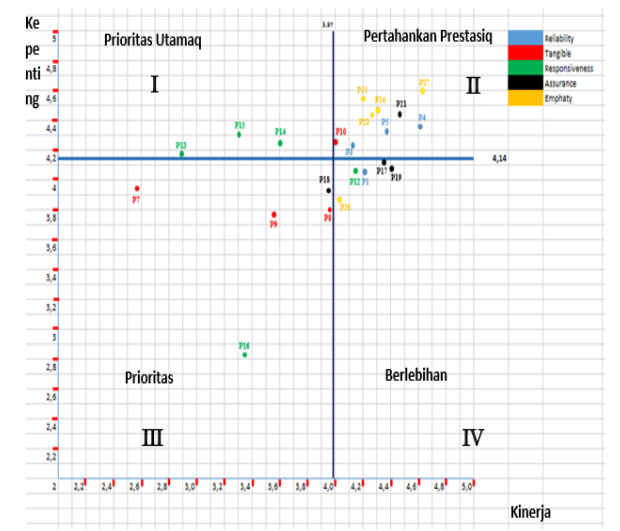

Gambar 2. Diagram Kartesius Analisis Indeks Performance Analysis

Keterangan :

\section{Reliability:}

P1 = Produk yang disajikan sesuai dengan pesanan

P2 = Jam operasi restoran sesuai harapan

P3 = Restoran selalu mengangkat telepon dari pelanggan

$\mathrm{P} 4 \quad$ = Produk yang dijual selalu fresh

P5 = Porsi setiap menu sesuai dengan harapan konsumen

\section{Tangible :}

P6 = Kebersihan alat dan perlengkapan makan terjaga

P7 = Tata ruang restoran baik
P8 = Peralatan makan yang tersedia lengkap

P9 = Meja kursi nyaman digunakan

P10 = Penampilan karyawan baik

P11 = Buku menu menjelaskan produk dan harga secara jelas

Responsiveness :

P12 = Pelayanan yang cepat

P13 = Pelayan stand-by dalam menanggapi konsumen

P14 = Pengaturan calon pelanggan ketika waiting-list baik

P15 = Pelayan segera membersihkan meja makan ketika konsumen selesai makan

P16 = Restoran selalu menerima saran dan masukan konsumen

Assurance :

P17 = Pengetahuan pelayan akan produk baik

P18 = Penjelasan produk di menu baik

P19 = Restoran selalu menginformasikan tanggal libur kepada konsumen

P20 = Kesesuaian menu dengan deskripsi pelayan

P21 = Adanya garansi penggantian produk apabila produk tidak sesuai pesanan/harapan konsumen

P22 = Adanya kepastian menu selalu ada (tidak pernah kosong)

Emphaty :

P23 = Pelayan fokus dalam melayani pelanggan

P24 = Pelayan berinisiatif menawarkan menu favorit kepada pelanggan

P25 = Kesediaan dan inisiatif pelayan untuk membantu ketika dibutuhkan pelanggan

P26 = Pelayan memiliki sopan santun yang baik

P27 = Pelayan memiliki kejujuran apabila ada barang pelanggan yang tertinggal 


\subsection{Analisis Customer Satisfaction Index}

Analisis Customer Satisfaction

Index (CSI) digunakan untuk mengetahui besarnya indeks kepuasan konsumen pecel lele lela. Pengukuran tingkat kepuasan konsumen sangat penting dilakukan untuk mengetahui seberapa besar harapan yang dapat dipenuhi oleh pihak pecel lele lela. Perhitungan Customer Satisfaction Index menggunakan nilai skor rata-rata tingkat kepentingan dan tingkat kinerja dari masing masing atribut. Analisis CSI apabila dikaitkan dengan hasil metode IPA, menunjukkan hasil nilai CSI yang diperoleh 79,738\% (Tabel 7) dengan didukung atribut-atribut pada kuadran II dan kuadran IV.

Tabel 7. Penghitungan Satisfaction Index

\begin{tabular}{|l|l|}
\hline $\begin{array}{l}\text { Satisfaction } \\
\text { Index }\end{array}$ & $79,738 \%$ \\
\hline
\end{tabular}

Atribut yang berada pada kuadran II dan kuadran IV tetap harus dipertahankan sehingga nilai CSI nya tidak mengalami penurunan. Mohsan; Nawaz ; Khan ; Shaukat, Aslam, (2011), Malik (2012). mengemukakan bahwa kepuasan konsumen erat kaitannya dengan loyalitas pelanggan. Nilai CSI yang belum mencapai 100\% disebabkan oleh adanya faktor dari atribut pada kuadran I dan III yang masih perlu diperbaiki dan ditingkatkan dalam waktu dekat, terutama atribut pada kuadran I.

\section{KESIMPULAN}

Berdasarkan uji validitas data, didapatkan 5 (lima) atribut pada kuesioner tidak valid. Sedangkan untuk uji reliabilitas menyatakan bahwa seluruh Aspek yang diteliti dapat diandalkan. Hasil analisis persepsi konsumen pecel lele lela menunjukkan bahwa dimensi yang menurut konsumen penting adalah dimensi responsiveness dan Emphaty. Berdasarkan hasil analisis Indeks Performance Analysis, atribut yang perlu ditingkatkan dan diprioritaskan untuk dibenahi adalah Pelayan stand-by dalam menanggapi konsumen, pengaturan calon pelanggan ketika waiting-list, dan pelayan segera membersihkan meja makan ketika konsumen selesai makan. Berdasarkan hasil penghitungan Customer Satisfaction Index, tingkat kepuasan pelanggan pecel lele lela perlu untuk meningkatkan dan memperbaiki atribut yang menjadi prioritas utama restoran. Perbaikan atribut yang menjadi prioritas utama pecel lele lela, yaitu dimensi responsiveness harus segera dilakukan dengan cara menambah jumlah pelayan stan-by serta menambah jumlah karyawan, agar kepuasan pelanggan pecel lele lela dapat terpenuhi dan juga meningkatkan kualitas restoran. 


\section{DAFTAR PUSTAKA}

Amirullah, Hardjanto I, 2005. Pengantar Bisnis, Edisi Pertama. Yogyakarta : Graha Ilmu.

(BPS). 2015. Penduduk Indonesia menurut Provinsi Tahun 2010 . Jakarta.

(BPS). 2015. Statistik Restoran. Daerah Khusus Ibu kota Jakarta.

(BPS). 2017. Rata-Rata Pengeluaran per Kapita Sebulan di Daerah Perkotaan dan Perdesaan Menurut Provinsi dan Kelompok Barang (rupiah), 2011-2017. Jakarta.

Gecti, F. Zengin, H. (2013). The Relationship between Brand Trust, Brand Affect, Attitudinal Loyalty and Behavioral Loyalty: A Field Study towards Sports Shoe Consumers in Turkey. International Journal of Marketing Studies, 5(2).

Ismail, T. Shaker. (2012). The Impact of product quality, perceived price and perceived value on the competitive capabilities of pharmaceutical companies in Jordan. AL-Quds Open University Journal. 26(1), 85 - 116.

Malhotra, NK. 2004. Marketing Research: An Applied Orientation. 4th Edition. New Jersey: Pearson Education Inc.

Malik, SU. 2012. Customer Satisfaction, Perceived Service Quality and Mediating Role of Perceived Value. International Journal of Marketing Studies. 4(1), 68-76.

Mohsan, F; Nawaz, M.; Khan, S.; Shaukat, Z. \& Aslam, N. 2011. Impact of Customer Satisfaction on Customer Loyalty and Intentions to Switch: Evidence from Banking Sector of Pakistan. International Journal of Business and Social Science. 2(16), 236-271.

Rangkuti, F. (2003). Measuring Customer Satisfaction: Teknik Mengukur dan Strategi Meningkatkan Kepuasan Pelanggan \& Analisis Kasus PLN IP. Jakarta: Gramedia Pustaka Utama.

Sugiyono. 2004. Metode Penelitian Bisnis. Alfabeta, Bandung. CV. Bandung. Swaid, Samar I, Wigand, Rolf T. 2012. The Effect of Perceived Site to Store Service Quality on Perceived Value and Loyalty Intentions in Multichannel Retailing. Internation nal Journal of Management. 29(3), 301-313.

Umar, H. 2002. Riset Pemasaran dan Perilaku Konsumen. Cetakan kedua. Jakarta: Gramedia. Pustaka Utama.

Wahyuningsih. 2007. Effects of Consumer Search Behaviour Typology on the Relationship Between Customer Sasifaction and Behavioral Intentions, 66-81.

$\mathrm{Xu}$, Y. Goedegeburre R. 2005. Employee Satisfaction and Customer Satisfaction: Testing the ServiceProfit Chain in a Chinese Securities Firm. Innovative Marketing Journal, (2).

Zeithmal, A.Z, Leonard, L.B, Parasuraman, A. 2006. The behavioral consequences of service quality, Journal of Marketing. 